\title{
Technological change and employment in Latin America: opportunities and challenges
}

\author{
Jürgen Weller
}

\begin{abstract}
The debate about what kind of impact current technological changes will have on employment is marked by a high degree of uncertainty, as is clear from the existence of widely differing estimates of the possible extent of job destruction. This article looks at various contributions to the analysis of how labour markets may be restructured and different projections of job destruction, job creation and changes in the nature of employment. A comparative consideration of the available evidence for developed countries and for the Latin American and Caribbean region based on a conditioned contextual approach leads to the conclusion that the impact of new technologies in the region will be shaped in part by the structure of production and of the labour market, the development of infrastructure and the relevant capacities of different sorts. Challenges in two areas of key importance in realizing the potential of new technologies to contribute to a sustainable development process and greater equality are then examined: workforce skills and competencies, and the regulation of labour relations.
\end{abstract}

\section{Keywords}

Employment, labour market, technological change, automation, unemployment, job creation, employment forecasting, labour relations, manpower, employment statistics, Latin America

\section{JEL classification}

J23, J24, O33

\section{Author}

Jürgen Weller was Chief of the Employment Studies Unit of the Economic Devleopment Division of the Economic Commission for Latin America and the Caribbean (ECLAC) until 31 December 2019. Email: jurgenweller@gmail.com. 


\section{Introduction}

The technological changes taking place today and those that are likely to occur in the near future are influencing a wide range of production activities and are opening up enormous opportunities for furthering development and attaining greater well-being, but they are also posing challenges and threats, especially in the area of employment. This combination of opportunities and challenges gives rise to a great deal of uncertainty which is, in turn, being reflected in widely divergent estimates of the possible extent of job destruction.

There is no doubt whatsoever that these technological changes will have a powerful impact on job destruction and creation and on future job profiles and the types of job skills that will be required. Employment relationships will also be altered as modifications in production processes drive the emergence of new modes of organization in both wage employment and emerging modalities of work.

The magnitude of these challenges is reflected, for example, in the oft-cited estimate that $65 \%$ of the children who are starting school now will have types of jobs and functions that do not even exist today (McLeod and Fisch, cited in World Economic Forum, 2016, p. 3). This underscores the challenges facing the region's education and vocational training systems.

While technological change is not the only process that will influence employment in the future, all of these elements will have a huge impact on the well-being of workers and society as a whole and on the associated distribution of benefits and costs.

In this article, the ways in which ongoing or future technological changes may influence labour markets will be explored from a conditioned contextual perspective, which posits that their impact will depend in large part on the decisions made by the actors concerned, although the range within which corresponding actions can be taken is determined by the characteristics of the technologies in question. This approach differs from the compensatory school of thought, which holds that the operation of the market will result in the creation of new jobs that will make up for the initial round of job destruction, and from the deterministic line of thought, which asserts that the impact on employment of technological change is solely determined by the characteristics of the technologies in question.

The following section sets out a number of general considerations regrading the impact of technological change on employment, while the third section reviews the recent literature on the subject. The fourth section covers job creation and destruction projections at the global level and specific projections for Latin America. The fifth section takes a closer look at two key areas for public policies aimed at influencing the employment impact of technological change: the regulation of new types of employment relationships; and skills-building and the development of areas of competence. The main conclusions drawn from this analysis are presented in the final section.

\section{General considerations}

Owing to the potential of technological changes to provide substitutes for human labour, such changes usually spark concerns about the emergence of a technology-driven surge in unemployment, on the one hand, and, on the other, expectations of improvements in the quality of life thanks to steep reductions in the amount of time people spend at work (Mokyr, Vickers and Ziebarth, 2015). As for the first aspect, Tarabusi (1997) differentiates among three types of unemployment on the basis of its causes and duration: short spells of unemployment caused by incremental technological changes at the company level; medium-term unemployment resulting from a major change at the sectoral level; and long-term unemployment brought about by a technical/economic paradigm shift in the economy as a whole. With 
regard to the second aspect, it suffices to recall the optimism expressed by Keynes, who, although he warned about the threat of technology-based unemployment, welcomed the technological changes of his time for their long-term impact on the quality of life of future generations. ${ }^{1}$

Technological change played a pivotal role in the development of capitalism in the nineteenth and twentieth centuries, mainly by spurring strong productivity gains thanks, for example, to the increasingly widespread use of electric and steam energy and the combustion engine, the various new machines that were being introduced in the textile industry and the appearance of the assembly line. As markets became more and more integrated, these increases in productivity (and, as a result, in competitiveness) created incentives for the introduction of these new technologies and - with the exception of certain specific niche markets - made it impossible for producers to remain competitive if they continued to use the older technologies. These technological advances consequently led to the elimination of jobs in occupations linked to production processes that were becoming obsolete.

These technologies did not only take the place of older ones that had been used to make the same products, however; they also opened the way for the appearance of a vast array of new products both by altering production and distribution processes and by bringing about changes in the way households were run (Gordon, 2016). As all this was taking place, a large number of new jobs were created that made up for the job losses caused by labour-saving technologies, and the earlier concerns that technological change would result in rampant unemployment were therefore not borne out in aggregate terms. In addition, thanks to social and political struggles, a number of positive changes were made in working conditions, such as the shortening of the workday and wage increases, which were facilitated by new productivity gains. ${ }^{2}$

The technological changes taking place now revolve around developments in such areas as quantum computing, the Internet of Things, cloud interconnectivity, robotics, big data, self-driving vehicles and artificial intelligence (ECLAC, 2017). This study will focus specifically on the sweeping changes brought about by information and communications technologies (ICTs) and the cognitive sciences and their related technologies, which, by bringing about the "universalization of the digital economy", have had the greatest impact up until now and are expected to continue to do so in the new future (ECLAC, 2016, pp. 60-62).

Current developments are not confined to specific sectors but instead are having an impact on all branches of activity, which are becoming increasingly integrated as the dividing lines between them become more and more blurred. The demarcation between the secondary and tertiary sectors is becoming fainter and fainter; for example, goods producers are finding that they have to incorporate services into their offerings, and in the case of ICTs, the production of hardware and software is becoming increasingly integrated.

The impact of new technologies on production processes is brought about by "the creation of digital goods and services, the addition of value by incorporating digital features into goods and services that in principle are not digital; and the development of production, exchange and consumption platforms" (ECLAC, 2016, p. 59). Schwab (2016) asserts that there are at least three reasons why today's transformations do not simply represent a prolongation of the third industrial revolution: their

\footnotetext{
1 Keynes saw the grand task of the future to be learning how to use free time wisely in order to lead a good life: "For many ages to come the old Adam will be so strong in us that everybody will need to do some work if he is to be contented. We shall do more things for ourselves than is usual with the rich to-day, only too glad to have small duties and tasks and routines. Three-hour shifts or a fifteen-hour week may put off the problem for a great while. For three hours a day is quite enough to satisfy the old Adam in most of us!" (Keynes, 1930, quoted in Mokyr, Vickers and Ziebarth, 2015, p. 41).

2 In a number of European countries, these technological changes coincided with a steep increase in the population (owing to the combination of high birth rates with a sharp decrease in mortality rates, especially infant mortality), which spurred mass emigration, especially to the Americas, in the nineteenth century and the first half of the twentieth. Without this "escape valve", the social and labour situation in many European countries would have become much more difficult than it did, which would have surely hampered the economic, social and political development of these countries.
} 
velocity, scope and impact on production, management and governance systems. He goes on to maintain that the (in part as yet potential) breadth and depth of these changes thus herald the arrival of a fourth technological revolution.

What lessons can we learn from past experiences about the impact of technological change on the labour market? What approach should be used in analysing the possible impact of new technologies on the quality of employment and the quantity of jobs? Tarabusi (1997) identified three such approaches:

(i) The compensatory line of thinking posits that, in undistorted markets, the efficiency gains generated by technical changes translate into a stronger demand for consumer goods (because they become less expensive) and for capital goods (which are needed to incorporate those same technical changes), which, in turn, reduces unit wage costs and generates a greater demand for labour. The market therefore automatically compensates for the job losses caused by technical change.

(ii) The deterministic school of thought theorizes that technologies have intrinsic characteristics that will determine their impact and that there is no real scope for influencing the resulting job destruction or the job qualifications or skills for which they will create a demand.

(iii) The contextual line of reasoning is based on the idea that new technologies' quantitative and qualitative effects on employment will depend on the existing institutional and organizational framework. The impacts of technical change are thus seen as varied and dependent upon the nature of social and political processes at differing levels and the macroeconomic environment.

The analysis presented in this article is based on the idea that new technologies are usually not confined to a single type of use and that their implementation does not have a linear impact. The specific ways in which they are used are determined by regulatory mechanisms that are specific to each society. It is not denied, however, that in order for new technologies to be efficiently applied in competitive market economies, the nature of those technologies generally does impose certain lines of action and certain constraints. Thus, it is argued that a proper analysis should start out by taking a relativized contextual approach. (An absolute approach of this nature would lead to the conclusion that the institutional and organizational framework would permit an arbitrary use of the technologies in question.) Technological determinism, which maintains that there is no scope - either legal or on the basis of negotiations between employers and workers - for regulating the use of technologies is ruled out, as is the compensatory approach, since the idea is not for just any type of job to be created but rather productive and decent forms of employment, as envisaged in Sustainable Development Goal 8.

\section{Recent trends: job destruction, job creation and changes in forms of employment}

The debate about the future impact of new technologies should include an exploration of the changes that they have recently brought about in the labour market. The job destruction seen in developed countries in recent decades that has been brought about by various factors, with one of them being technological change, has primarily involved cognitively or manually routine functions. This has given rise to a polarization of the occupational structure, with the creation of jobs in occupations involving non-routine cognitively intensive activities (i.e. functions that can only be performed by highly educated persons) and jobs in occupations involving non-routine manual jobs that are generally performed by people with lower levels of formal education (see figure 1). ${ }^{3}$

\footnotetext{
3 See the discussion on the polarization of the occupational structure in the United States in Acemoglu and Autor, 2012.
} 
Figure 1

Developed countries: average annual variation in the percentage of types of employment involving different levels of qualification, from around 1995 to around 2012

(Percentage points)

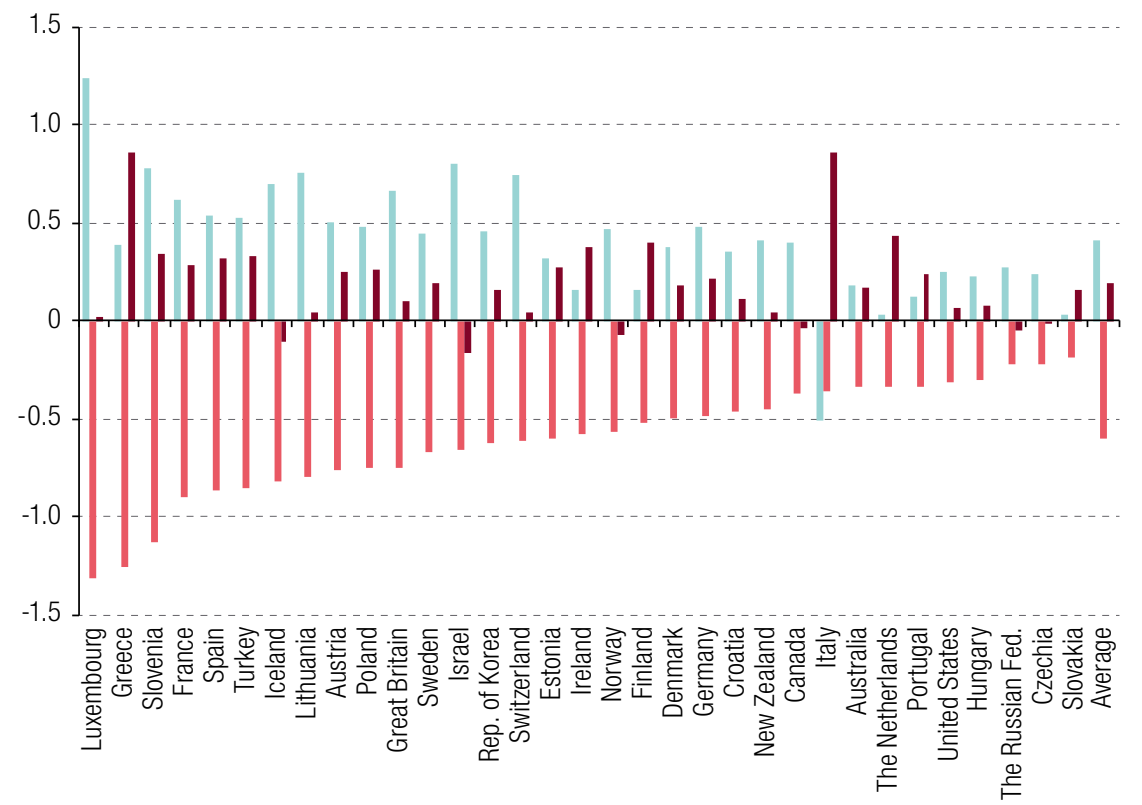

High-skilled occupations (non-routine cognitive and interpersonal skills)

- Low-skilled occupations (intensive in non-routine manual skills)

Middle-skilled occupations (routine cognitive and manual skills)

Source: Prepared by the author on the basis of data from World Bank, World Development Report 2016: Digital Dividends, Washington, D.C., 2016.

For developed countries, on average, between around 1995 and 2012, occupations based on routine cognitive or manual tasks shrank by 0.6 percentage points as a proportion of total employment, while the share of jobs based on non-routine cognitive and interpersonal tasks or non-routine manual tasks expanded by 0.4 and 0.2 percentage points, respectively. This shift in the occupational structure is attributable to a variety of factors, one of which is technological change, as the increased use of ICTS in manufacturing and services is positively correlated with the proportion of jobs involving non-routine functions (OECD, 2017, p. 46).

This type of polarization is also found in low- and middle-income countries, although it is not as widespread as in the case of high-income countries (World Bank, 2016). Figure 2 depicts the results for the countries of Latin America and the Caribbean for which information is available.

As an average for the countries of the region for which information is available, the intermediate segment's share in the occupational distribution slipped by 0.4 percentage points, while the share of the high-skilled and low-skilled segments expanded by 0.3 and 0.1 percentage points, respectively.

The results of a similar study of 30 countries in Latin America and the Caribbean covering the period 1995-2015 conducted by the International Labour Organization (ILO) (2016c, p. 55) were somewhat different. Although that study also showed that the highest growth rate (over $3.5 \%$ per year) was for occupations involving non-routine cognitive tasks, it found that highly routine occupations expanded more than non-routine manual ones (2.3\% and $1.6 \%$, respectively). ${ }^{4}$ In any case, that study also pointed to a trend towards more highly skilled occupations. A study by Aboal and Zunino (2017)

\footnotetext{
4 These figures are based on ILO calculations and estimates (2015) and include some larger countries not covered in the World Bank study, such as the Bolivarian Republic of Venezuela, Brazil and Colombia.
} 
on the impact of innovation in the manufacturing industries of three Latin American countries also confirmed the existence of this trend, as in two countries (Argentina and Uruguay) innovation had a stronger positive impact on skilled job creation than on unskilled job creation, while, in Costa Rica, it had a very similar impact on both occupational categories.

\section{Figure 2}

Latin America and the Caribbean: average annual variation in the percentages of job categories, by skill level, around 1995 and around 2012

(Percentage points)

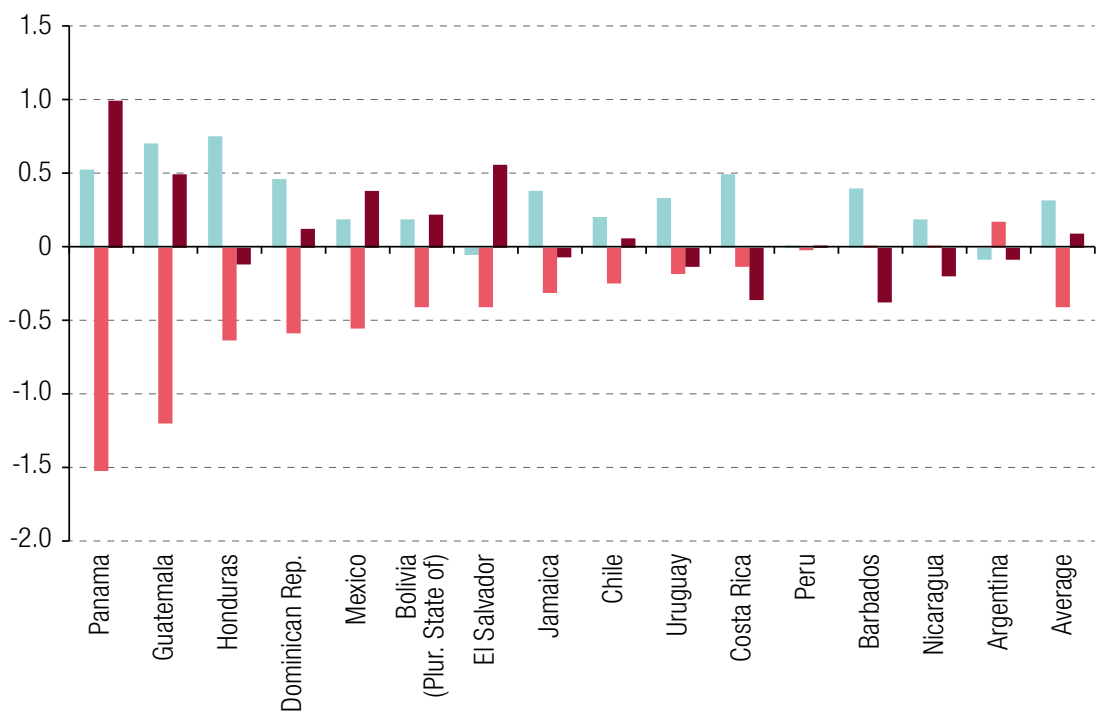

High-skilled occupations (non-routine cognitive and interpersonal skills)

- Low-skilled occupations (intensive in non-routine manual skills)

Middle-skilled occupations (routine cognitive and manual skills)

Source: Prepared by the author, on the basis of data from World Bank, World Development Report 2016: Digital Dividends, Washington, D.C., 2016.

As in previous technological revolutions, the job losses caused by technological changes are paired with the creation of new jobs, and the strength of this latter phenomenon has often been underestimated. Acemoglu and Restrepo (2016) contend that technological change and automation are precisely what is creating new increasingly complex occupations. According to these authors, between 1980 and 2007 approximately half of all the jobs created in the United States were in occupations that did not even exist in 1980. This would indicate that potential job creation is highly unpredictable. These authors also argue that self-correcting mechanisms are at work, as automation tends to depress wage levels, making the creation of new jobs more profitable, although goods market and labour inefficiencies may block that process and, if technological changes are of a type that speeds the development of new innovations, they may have a more adverse effect on labour. An empirical analysis carried out by those same authors led them to conclude that robots have had a significantly negative impact on local labour markets in the United States in terms of both the number of jobs and wage levels, which means that any possible compensatory effect has not been strong enough to result in the creation of an equal number and quality of jobs as those that have been destroyed (Acemoglu and Restrepo, 2017).

Graetz and Michaels (2017) confirm earlier findings that technological change has been associated with the low labour intensity of recent post-recession recoveries in the United States since 1990, especially in routine-intensive industries that are more exposed to automation. They did not, however, find this to be the case in other developed countries. 
Aside from the structural aspects of these trends, the phase of the economic cycle also influences the immediate impact of technological changes in the aggregate. Depending on the prevailing circumstances in an economy (which are in part a result of the momentum generated by technological change), the loss of certain types of jobs may be counterbalanced to a greater or lesser degree by the emergence of new jobs. In the United States, Aaronson and Phelan (2017) found that, among low-wage jobs, those in which routine but cognitive tasks predominated were the most likely ones to be replaced. In a swiftly growing economy, many of the people who lost their jobs in these types of occupations succeeded in finding other employment but at lower pay levels.

Another example is provided by an empirical study by Hathaway and Muro (2016), who analysed the impact of the introduction of business platforms in the transportation and temporary housing rental sectors in the United States. They found that, as employment linked to those platforms expanded, not only did the numbers of jobs in more traditional activities in those industries not decrease but they actually rose, although more slowly.

Under certain circumstances, labour-saving technological changes actually promote job creation. Bessen (2015) cites the case of the introduction of automatic teller machines, which was supposedly going to result in a sharp reduction in financial service jobs and especially in bank teller positions. However, the restructuring and expansion of the business (in part owing to the cost savings brought about by that new technology) led to the creation of new types of tasks, and the number of bank employees actually rose.

Thus, employment trends reflect not only the impact of technological change but also the general situation in an economy. Developed countries are currently in a growth phase, but there is no guarantee that job creation will continue at its present pace. Nevertheless, it is clear that, viewed in dynamic terms, the impact of new technologies on employment is more complex than simply the replacement of people's jobs by machines or other types of work, as is usually argued by advocates of technological determinism.

\section{The outlook for changes in employment and in occupations}

Before looking at the results of a number of studies on the impact of technological change on employment, it should be noted that, in addition to the macroeconomic situation, employment trends are also influenced by other long-term factors such as demographic changes, economic growth and the restructuring of production (e.g. changes in value chains and efforts to reduce various industries' carbon footprints). ${ }^{5}$

Some experts are of the view that the most endangered occupations will continue to be those that entail a large proportion of routine work. For example, the McKinsey Global Institute (2017a) has said that middle-skill jobs are the most susceptible to automation and specifically mentions physical activities in highly structured and predictable environments and the collection and processing of data as the areas under the most threat. Thus, technological change would appear to be maintaining the polarization of the occupational structure that has been seen, especially in developed countries, in recent times. KPMG International Cooperative (2016) projects that middle-income routine jobs are the ones that are most likely to be replaced by cognitive platforms in the future, while Manpower Group (2017) believes that low- and middle-skilled jobs are the ones under the greatest threat. What is clear is that,

\footnotetext{
5 In the United States, the Bureau of Labor Statistics has projected that the largest numbers of new jobs created in 2016-2026 will be in the health-care industry, business and financial operations, food preparation and service, and personal care (cited in World Economic Forum, 2018). The McKinsey Global Institute (2017b) has estimated the net impact of automation and the number of new jobs that will be created as a result of a number of these trends for six countries with differing levels of per capita income.
} 
as further changes take place in production and the labour market, the big losers will be people with low skill profiles, especially if there are obstacles that prevent them from acquiring the knowledge and skills required by the new job options that will be opening up.

Women may also be strongly affected by this changing landscape. Many women are employed in middle-skilled occupations - such as administrative jobs, sales and financial operations - that are threatened by new technologies, whereas they are underrepresented in university careers and some of the occupations that have a strong potential for expansion. ${ }^{6}$

Other researchers have focused on the cross-cutting impact of present and future technological changes on a wide range of occupations (Krull, 2016, p. 20). Some of them believe that, in addition to the routine activities that have been most affected by automation in the past, these changes will also affect jobs requiring intermediate or advanced qualifications, as well as middle- or low-skilled non-routine activities (e.g. in retail trade, transport and social services). Cases in point include the automation of many administrative tasks; expanding sensor capacity and cloud robotics, which may make machines much more mobile than they are today; artificial intelligence and the "deep learning" algorithms that function without human intervention; and probability-based decision-making processes, which are facilitated by the exponential growth of hardware technologies (Pratt, 2015).

The introduction of these new technologies is taking place in a globalized world where production has become internationalized, with global value chains being composed of production processes located in various countries. The consideration of the possible impact of technological changes should therefore take into account the ways in which value chains may be affected by these changes as well.

Two opposing trends can be observed in this respect. On the one hand, by reducing the cost of capital, new technologies are altering the relative prices that served as a basis for the development of these chains while at the same time increasing the importance of their cognitive components. What is more, the distance between each link in the chain and between its final component and its end market can become a problem. In this specific context, the importance of cheap labour as a factor of production may be lessened. For a few years now, there have been signs of the reversal of some offshoring processes, with certain types of production units being repatriated from low-wage countries to developed ones, especially as global economic growth slows (Kinkel, 2012; Saxer, 2017). As the growth of world trade slackens, these changes may be reflected in the strategies of many companies, as almost all labour-intensive industries that have not been automated have already been moved from developed countries to low-wage countries (Wolf, 2016; ILO, 2016a).

On the other hand, business platforms may facilitate the extension of the practice of outsourcing services such as administrative support, financial operations, sales and others to include skilled work in a wide variety of occupational areas. There are many different forms of outsourcing, ranging from the use of established teams to crowdworking or similar approaches. This may give rise to new types of global interaction in, for example, the area of problem-solving, that may be network-based rather than chain-based.

In recent years a series of quantitative estimates have been developed of technology-driven job destruction and job creation and of the net outcome. For developed countries, Frey and Osborne (2013) have made some of the most pessimistic projections, as they estimate that $47 \%$ of existing jobs in the United States may be replaced by technology in the not-too-distant future. Autor (2013 and 2015) questions these results, arguing on the basis of the "task approach" that a variety of tasks are bundled into many occupations and, if new technologies come into use that take the place of human labour for some of those tasks, that does not necessarily imply that the job itself will be eliminated in many

\footnotetext{
6 See OECD (2017). The United States Bureau of Labor Statistics estimates that $57 \%$ of the jobs that will be done away with between 2016 and 2026 are held by women (cited in World Economic Forum, 2018). This marks a change from previous job losses, especially in manufacturing, which hit men the hardest (Miller, 2017).
} 
cases. Since there is apparently a tendency for individual workers to perform a growing number of tasks, replacing an entire human worker with technologies that will automate specific tasks becomes a more complex undertaking. ${ }^{7}$ Consequently, what may occur is that new combinations of ways in which these tasks are performed may arise (Akçomak, Kok and Rojas-Romagosa, 2016). Estimates of job destruction arrived at using this approach naturally are lower. For example, Arntz, Gregory and Zierahn (2016) estimate the proportion of jobs at high risk of substitution in the countries belonging to the Organization for Economic Cooperation and Development (OECD) at 9\%.

The McKinsey Global Institute (2017a) also takes occupational and task differentiation into account in analysing the potential substitution of 2,000 activities spread across 800 occupations. That study found that around half of those activities could be automated by existing technologies (between $41 \%$ and $56 \%$, depending on the country) but that less than $5 \%$ of those occupations could be entirely automated, while $60 \%$ of them have at least $30 \%$ of constituent activities that could be automated, leading to the conclusion that those occupations are more likely to change a great deal than to be automated away. The scenario that served as a basis for that study is one in which about $50 \%$ of those activities could be automated by 2055, but the authors emphasize that this time horizon may be influenced by a series of factors. In a later study by the McKinsey Global Institute (2017b), the same group of authors use a midpoint scenario in which $15 \%$ of the hours now worked worldwide would be automated by 2030 , but they allow for a wide margin in which that number could vary from only slightly more than $0 \%$ up to $30 \%$.

And what about Latin America? Few projections are as yet available. Using the methodology developed by Frey and Osborne (2013), the World Bank (2016) found that, of the 11 Latin American countries that it analysed, between 62\% (Dominican Republic) and 75\% (El Salvador and Guatemala) of jobs might be automated, with the average for the 11 countries being $67 \%$ (compared with $57 \%$ for the OECD countries). If the lag in the adaptation of new technologies typically found in less developed countries is taken into account, the range drops somewhat to the still quite high levels of between $40 \%$ (Nicaragua) and 65\% (Argentina), with an average figure of $49 \%$ for the countries of the region.

Interestingly enough, while the unadjusted average for the Latin American countries is higher than the average figure for OECD, when the numbers are adjusted for the lag in switching production processes over to new technologies typical of poorer countries in which knowledge assets are in scarcer supply, then the average for Latin America is lower than the OECD average.

Also using the methodology of Frey and Osborne (2013), Aboal and Zunino (2017) arrive at similar results for Argentina (64.1\% probability of automation) and Uruguay (66.4\%), with slightly higher rates for men than for women.

OECD, the Andean Development Corporation (CAF) and ECLAC (OECD/CAF/ECLAC, 2016, p. 263) estimate the net loss of jobs for Latin America as a whole, based on data compiled by the World Economic Forum and ILO, at 3.38 million (between 1\% and 2\% of all jobs) by 2030. Projections place the losses chiefly in the manufacturing sector, with the destruction of around 3.5 million jobs; administrative and support positions, with a loss of around 1.3 million jobs; and the construction industry, which is expected to lose slightly over 1 million jobs. These losses will not be entirely offset by the projected gains in retail trade (slightly over 2 million new jobs), transportation (around 500,000) and other branches of activity.

Using the task approach to analyse a limited group of Latin American countries, McKinsey Global Institute (2017a) finds the highest percentages of automatable activities (over 51\%) in Colombia, Costa Rica, Mexico and Peru, followed by Brazil, Argentina, Chile and the Dominican Republic

\footnotetext{
7 Becker and Muendler (2014) found a sharp increase in the number of tasks that German workers report performing (a rise from 1.67 in 1979 to 7.24 in 2006, on average). The creation of global supply chains that break the production process down into specialized steps presumably works against this trend (see ILO, 2016a).
} 
(between $45 \%$ and $47 \%$ ). As mentioned earlier, the time horizon for these projections is 2055 . For the updated base scenario used by the McKinsey Global Institute (2017b), that study puts the proportion of activities (not jobs) that will be automated between 2016 and 2030 at around 7\% for Peru and around $14 \%$ for Brazil.

It should be remembered that the replacement of activities does not necessarily translate into job losses. If the estimate of the McKinsey Global Institute (2017a) of the impact of technological changes at the global level (5\% of occupations become completely automatable) are applied to Latin America, then the region stands to lose around 14 million jobs in that time period.

However, the technological changes in question are unlikely to have any direct effect on the informal sector, since it generally employs technologies that are far from the leading edge of innovation or technology. If this structural difference between the labour markets of Latin America and developed countries is taken into account and the above percentage is applied only to sectors with intermediate or high levels of productivity, then the figure for job losses drops to approximately 8 million. This would be the minimum number of jobs replaced by technology, since, in addition to these completely automatable positions, other jobs that are not 100\% automatable could still be subject to replacement.

Given the way the labour market operates in Latin America, Weller and Kaldewei (2014, pp. 68-72) posit that many of the people who lose their jobs will become employed in the informal sector if they cannot find work in other occupations in the formal sector, rather than remaining entirely unemployed or leaving the workforce altogether. The effect of the loss of a large number of formal sector jobs as a result of technological change is therefore likely to be an increased informalization of the occupational structure.

In line with these considerations, Weller, Gontero and Campbell (2019) adjusted the methodology of Frey and Osborne (2013) to take the structural differences between Latin American and developedcountry labour markets into account. They found that, for a group of 12 countries in the region, the proportion of jobs at high risk of substitution drops from the range of between 25\% for Brazil and 55\% for El Salvador and Guatemala that was computed using the original methodology to a range of between $5 \%$ for the Plurinational State of Bolivia and 29\% for Uruguay when the adjusted methodology is used; they also found that the proportion of jobs at high risk of being replaced by technology is greater in the Latin American countries with a higher per capita GDP and larger mid-and high-productivity sectors (see figure 3). The lower risk level for the region compared to developed countries is, however, a reflection of the continued existence of low-productivity sectors in which, for many workers, employment serves primarily to maintain their households at a subsistence level and which have little capacity for introducing new technologies or reallocating factors of production on a competitive basis, and the jobs that will be left in these sectors are typically of poor quality.

The studies discussed above, most of which are based on the opinions of experts or corporate managers, dovetail with the views of employees in formal sector enterprises. According to a survey conducted by Randstad (2016), in the Latin American countries that it covered (Argentina, Brazil, Chile and Mexico) between 45\% of workers (Mexico), and 60\% (Brazil) think that they perform repetitive work or routine tasks that could be automated. It is noteworthy that managers' and workers' assessments of the number of jobs that could be affected by automation are so similar and are higher than the worldwide average (44\%). On the other hand, the proportion of Latin American workers who believe that, if their repetitive tasks were automated, they could add more personal value to their work, is also higher than the global average (between $70 \%$ and $74 \%$ versus $62 \%$, respectively). This finding clearly reflects the optimistic view that the automation of routine tasks would boost the productivity and quality of jobs rather than destroying them. 
Figure 3

Latin America: estimated proportion of jobs at a high risk of being replaced by technology based on the original and adjusted versions of the Frey and Osborne methodology

(Percentages)

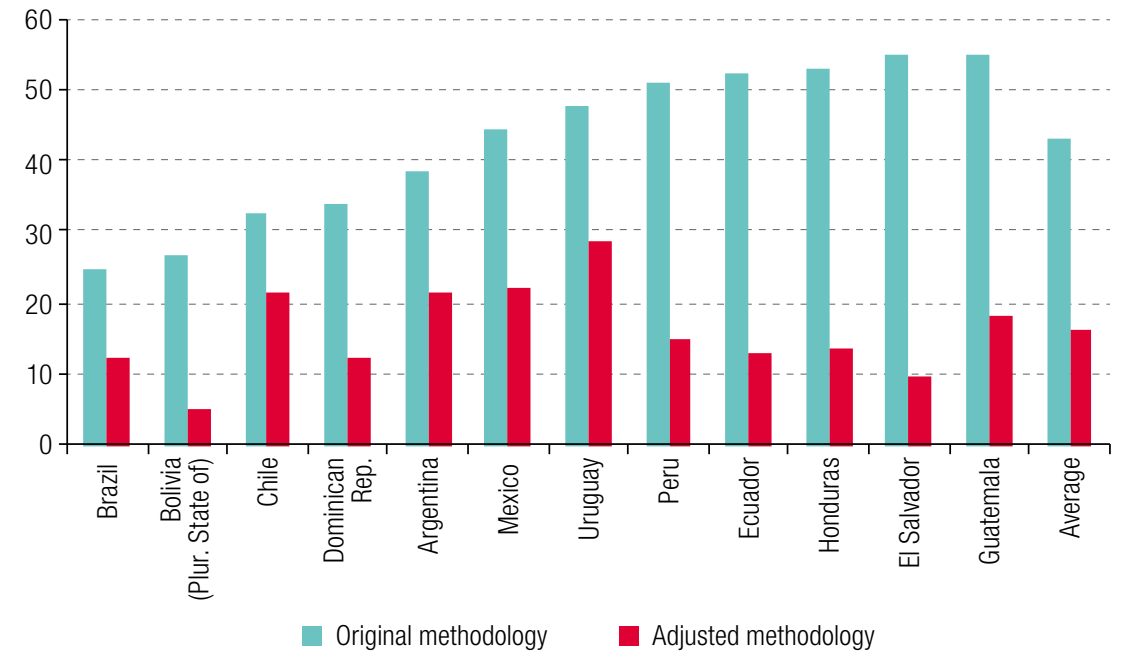

Source: Prepared by the author, on the basis of J. Weller, S. Gontero and S. Campbell, "Cambio tecnológico y empleo: una perspectiva latinoamericana. Riesgos de la sustitución tecnológica del trabajo humano y desafíos de la generación de nuevos puestos de trabajo", Macroeconomics of Development series, No. 201 (LC/TS.2019/37), Santiago, Economic Commission for Latin America and the Caribbean (ECLAC), 2019.

Returning to the projections made by corporate experts, it is interesting to note that many Latin American companies have indicated that, in the very near future (a two-year time span), they expect to take on more employees as a consequence of the digitization of their operations. The eight Latin American countries covered by a survey conducted by the Manpower Group (2018) reported that they planned to hire more people, and Latin America was the most optimistic region of all in that respect. In contrast, a majority of the respondent companies in 7 out of a total of 23 European countries said that they expected a reduction in their workforce in response to digitization and, in those that did expect to hire more workers, the projected number of additional employees was smaller than in the case of the Latin American firms. This discrepancy between favourable expectations in the short run and a more negative outlook for the long term may be explained by the fact that, in a relatively brief period of time, many Latin American companies will need to incorporate new technologies into their production processes in order to remain competitive and will therefore need to hire ICT specialists, while the possible labour-saving impact of those technologies will be felt later on. In contrast, this process is already quite advanced in the developed countries. If this is the case, then this situation can be viewed as a reflection of the lag in the introduction and adaptation of new technologies that has long been a characteristic of the Latin American development process.

What specific factors play a part in the differentiation of the impact of new technologies in terms of job substitution in mid- and high-productivity sectors in Latin America? It must be remembered that not all tasks whose replacement is technologically feasible will necessarily be automated (Bensusán, Eichhorst and Rodríguez, 2017). The factors that influence the probability of a given job being replaced by technology can be summed up as follows:

$$
P S=f\left(+\delta P L_{i},+w_{i},+P T_{i},-C 1_{i},-C 2_{i},+I_{i},+x_{i}\right)
$$

where the probability of substitution (PS) of a given job in sector $i$ rises in step with the productivity differential between the new and old technologies $\left(\delta P L_{i}\right)$, the cost of labour $\left(w_{i}\right)$ and the proportion of the tasks bundled into that job which lend themselves to substitution $\left(P T_{i}\right)$. This probability declines, on the 
other hand, as the cost of introducing the new technology $\left(C 1_{i}\right)$ rises (this includes the cost of acquiring it, making any necessary adjustments, installing it, training employees to use it and any necessary modifications in the workplace, among others) and as the cost of maintaining and updating it $\left(C 2_{i}\right)$ increases.

The impact of the available capacity for technological innovation and adaptation and the available organizational capacity in an economy and a specific sector $\left(I_{i}\right)$ is uncertain. On the one hand, the presence of a high level of innovation capacity tends to be accompanied by the introduction of more labour-saving technologies; on the other hand, if innovation capacity is low in occupations with a large proportion of automatable activities, it will be difficult to devise efficient ways of combining new technologies with the non-automatable tasks that still need to be performed by human beings. This will then pose the risk of a loss of competitiveness (in tradable goods and services) that would in turn destroy the jobs in question.

Finally, there is another set of factors $\left(x_{i}\right)$ whose impact is uncertain. These factors include such aspects as outside infrastructure requirements, aspects specific to the sector concerned (e.g. expectations for growth and for changes in market structure and future technological development) and aspects specific to the company in question.

In the case of Latin America, where wages are low, much greater productivity gains would be needed in order for substitution to be profitable. ${ }^{8}$ Furthermore, the capacity for technological and organizational innovation and adaptation is, on average, lower in the region than it is in developed countries and, in the case of many of the new technologies, the $C 1_{i}$ and $C 2_{i}$ costs are presumably higher owing, for example, to the costs associated with the importation of technologies and to the fact that adaptation costs may be higher as well because there are fewer specialists with the necessary expertise to introduce new technologies and to do the necessary follow-up work (e.g. maintenance and training). Finally, outside infrastructure may be needed that will require public investments that may not always be forthcoming.

Consequently, there are a number of factors that make it less likely that jobs will be replaced by new technologies in Latin America, as the gap between technologically possible and economically viable job substitutions is greater than it is in developed countries. However, while this indicates that fewer jobs are likely to be replaced by technology in the region, which would seem to be good news, the fact remains that this conclusion is based on the existence of economic lags and gaps (in infrastructure, innovation capacity, productivity and wages, for example) that the region should be attempting to close as part of the its sustainable development strategy.

Finally, an analysis of the relationship between technological change and employment must take indirect impacts into account as well. According to Berger, Chen and Frey (2017), job creation in the services sector via the multiplier effect of skilled job creation in the manufacturing sector is greater in developing than developed countries, which may lessen, in the aggregate, the impact of new labour-saving technologies.

\section{Policies for guiding and supporting technological change}

If the introduction of new technologies is viewed from a conditioned contextual perspective, it becomes clear that public policy has a pivotal role to play in various areas, ranging from technological development as such to the approaches to be used for incorporating technologies into production processes and mitigating their undesirable but unavoidable impacts.

\footnotetext{
8 Persons employed in comparable occupations usually earn much lower wages in less developed countries (Freeman and Oostendorp, 2000).
} 
The actual impact that these technological changes will have on employment in quantitative and qualitative terms will depend in large measure on how they are handled. Therefore, in many countries (especially developed ones), these processes are not left entirely in the hands of market forces. Instead, special programmes are put in place to promote their development and introduction into the production sector and society at large (Bensusán, Eichhorst and Rodríguez, 2017). This is an area of policy in which Latin America and the Caribbean lag far behind (Cimoli and others, 2017). ${ }^{9}$

Two areas of policy that are closely related to the impact of technological changes on employment will be discussed in this section: the regulation of labour relations, and the development of the skills and capabilities required to take advantage of their potential. ${ }^{10}$

\section{The regulation of labour relations}

The nature of labour relations varies widely across Latin America (Bensusán, Eichhorst and Rodríguez, 2017; Novick, 2018). This heterogeneity is the outgrowth of a number of different phases in the region's history. The informal sector has traditionally accounted for a large proportion of the jobs in the region's economies, and the concept of "atypical employment", as opposed to employment in the predominantly formal labour markets of developed countries that arose during the post-war period, is therefore not applicable to the region. The formal sector also includes a sizeable number of informal jobs, in many cases as a result of corporate cost-cutting strategies. Moreover, during the 1990s many Latin American countries introduced new types of formal employment that differ from the traditional type of full-time, permanent employment, such as part-time work and fixed-term contracts.

The technological changes now taking place have also given rise to new types of employment relationships in Latin America, such as those associated with the gig economy and the "sharing economy" (Artecona and Chau, 2017; IE/IDB/MIF, 2016). Thus, the technological changes now under way are giving rise to a trend towards increasingly heterogeneous ways of working that are posing new challenges for labour institutions.

Some of these new employment modalities tend to depress people's earnings, such as in the case of crowdworking, in which a company can seek inputs from an unregulated global source of supply. The "winner takes all" modality, in which an employer pays only for the work that turns out to be most useful for it, is an especially precarious one for workers, as all those involved except the "winner" go unpaid (Krull, 2016, p. 16).

In addition to the fact that, in many cases (although obviously not in all), the income streams from these new modalities are unstable, new technologies have also opened up new ways of monitoring workers (Krull, 2016, pp. 19 and 24). These technologies make it possible to generate huge amounts of data that facilitate an increasingly detailed tracking of workers' activities. Another increasingly important aspect (as in the case of Uber drivers, for example) is the ability to disseminate reviews of people's work, thereby creating a reputation that may provide - or block - access to job opportunities.

The pressure on people to remain connected with information networks at all times tends to be a source of overload and stress. What is more, the lack of full-time work may oblige people to hold a number of different jobs, interferes with the workings of traditional labour institutions and blurs the line between work and private life (OECD/CAF/ECLAC, 2016, p. 264). A number of countries (including many in Latin America) have therefore proposed legal initiatives for helping people to disconnect outside of working hours and to achieve a better work/life balance (Diario Financiero, 2017a).

9 ECLAC (2016) has advocated linking these aspects with an increase in investment in what it has called an "environmental big push" in Latin America.

10 Other relevant issues include, for example, fiscal policy and the possibility of levying a tax on robots (Shiller, 2017), the protection of people hurt by technological changes by guaranteeing a universal basic income (United Nations, 2017) and the possibility of shortening the workday (Mokyr, Vickers and Ziebarth, 2015). 
The growing heterogeneity of types of employment has sparked a debate around the question of whether or not specific regulations need to be framed for the various types of relationships existing between workers, clients and employers or intermediaries (traditional employers, outsourcers, Internet business platforms and so forth) or if regulators should simply use certain key indicators to determine whether a person is a wage earner (albeit with certain specificities) or an independent or own-account worker (Bensusán, Eichhorst and Rodríguez, 2017; ILO, 2016b). Either option involves a number of complex tasks. In the first case, the challenge will be to design regulations for the new forms of work that comply with the mandates of labour institutions while offering an appropriate mix of efficiency and protection. In the second case, regulators would have to ensure that wage earners receive the benefits that they are entitled to under a country's labour laws while moving towards the formalization of independent work by clearly establishing the rights and duties associated with this occupational category.

Wage earners and their labour institutions are also encountering new challenges. For example, the question arises as to whether the automation of large segments of the production process undermines the right to strike (Diario Financiero, 2017b).

The analysis of the impact of technological changes on labour relations and the design of the corresponding regulations should be a participatory process that includes labour unions and workers in the activities where these new types of employment relationships are taking shape, along with corporate employers. It is often argued that the regulation of these activities can interfere with efforts to take advantage of the potential for boosting productivity. However, realizing that potential on the back of a reduction in the quality of employment will hinder the creation of virtuous circles of productivity, labour income and non-wage aspects of employment quality that serve as the foundation for the economic and social sustainability of the prevailing economic model.

Since there is no first-best solution for the implementation of new technologies (as advocates of technological determinism would argue), this needs to be the outcome of participatory efforts that provide a framework for a learning process. Bensusán, Eichhorst and Rodríguez (2017) assert that the application of labour regulations to new employment modalities should be based on negotiation and dialogue. ${ }^{11}$ In this context, Sundararajan (2017) advocates the reformulation of the social contract to take account of the labour force's growing heterogeneity, while Adigital/GOVUP (2017) highlight the importance of cooperative efforts on the part of public agencies and platforms to facilitate the collection of taxes and social security contributions, the possibility of platforms functioning with a mix of types of employee relationships on the basis of agreements with workers, the need for a clear delimination of what constitutes own-account work, the establishment of wage and social protection floors, the importance of having third-party liability insurance schemes and the need to provide greater access to information on workers' and employers' rights and duties.

Participatory processes tend to result in more centrist, socially acceptable arrangements (neither total deregulation nor overly strict regulation). For example, on the one hand, a lack of regulation of platform-based passenger transportation businesses has led to the persons employed in those businesses to form movements of their own to protest poor working conditions and to demand suitable benefits; yet, on the other hand, the evidence indicates that many of the people taking part in these new modalities value the flexibility that they provide. ${ }^{12}$ Another consideration is that people's views about the money they earn from these new types of arrangements differ depending on whether this is income that supplements the wages people earn from their main job and is earned in their free time or if it is a person's main source of income, in which case, aspects such as the variability of working

\footnotetext{
${ }^{11}$ Along these lines, the Ministry of Labour of Germany has underscored the importance of cooperation between employers and workers and has advocated the pursuit of a joint learning experience within the framework of this paradigm shift, using it as the starting point, and of a trial period to test out new concepts on an experimental basis (BMAS, 2017, p. 13).

12 In a survey of the members of the German trade union Vereinte Dienstleistungsgewerkschaft (ver.di), own-account workers reported a high degree of satisfaction with their work, they also said that they were concerned about the instability of their incomes and about retirement (Koch, 2017).
} 
hours or earnings are a much more important consideration. A final point is that there appears to be an increasing variability in the values that determine workers' preferences in terms of their forms of employment (BMAS, 2017, pp. 36-37).

\section{Skills and capabilities required to take advantage of the potential of new technologies}

While a great deal of uncertainty remains about the impact that technological changes will have on employment, there is a broad consensus that education and vocational and professional training are crucially important tools for capitalizing on the potential benefits of these changes and for limiting their negative impact. ${ }^{13}$ With regard to the realization of these technologies' potential, it has been argued that the reason why labour productivity is rising so slowly in developed countries, despite the introduction of new technologies, is that few managers and few workers have the necessary knowledge and skills to take full advantage of them (Baily and Montalbano, 2016). ${ }^{14}$ If this is the case, then once the bottlenecks are cleared away by the right kinds of training and education, major productivity gains can be made (and the lag in the realization of those gains will have been similar to the lags observed in other technological revolutions).

As a result of the job destruction and the disappearance of some occupations that this will entail, an undetermined number of people will lose a large part of their human capital and will therefore need to be retrained for other occupations. Experience has shown that this is not a smooth process (Miller, 2017). An interesting perspective has been presented by the World Economic Forum (2018), which suggests that people who lose their job may be retrained for an occupation that, according to certain criteria, is quite similar to their previous one.

There is a general consensus that the skills that people need in order to perform successfully in jobs involving the use of new technologies are primarily non-routine cognitive ones. However, recent studies indicate that the most important factor in the successful performance of such jobs is the possession of a combination of these skills with interpersonal and social skills (such as problem-solving and communication skills and teamwork) that cannot be readily replaced by new technologies (OECD, 2017; Edin and others, 2017; Manpower Group, 2018).

Unfortunately, comparative international studies indicate that the countries of Latin America and the Caribbean lag far behind both developed countries and some emerging ones in terms of basic skills (as measured by the OECD Programme for International Student Assessment (PISA) test) and the competencies needed in the workplace (as measured by the OECD Programme for the International Assessment of Adult Competencies (PIAAC)) (Fiszbein, Cosentino and Cumsille, 2016; OECD, 2017).

In both developed countries and in Latin America and the Caribbean, there appears to be a mismatch between the skills people acquire at school and in training courses, on the one hand, and the skills required on the job, on the other, as is attested to by employers' frequent complaints that they are unable to find people who have the qualifications that they need. ${ }^{15}$ This mismatch is also evident in the high youth unemployment rates seen in Latin America and the Caribbean, even among highly educated young people. In order to address this problem, the skills that are and will be in demand need to be identified more accurately (Novick, 2017), the necessary adjustments need to be made in educational curricula and in professional and vocational training courses to align them with those skill

${ }^{13}$ See, for example, Fiszbein, Cosentino and Cumsille (2016); OECD (2017); World Economic Forum (2018); and Manpower Group (2018).

${ }^{14}$ Even in the OECD countries, there appear to be wide gaps between the skills that will be in demand in the future and the qualifications of today's workforce, as $56 \%$ of the adult population in those countries have no more than basic ICT skills or none at all (OECD, 2016).

${ }^{15}$ See, for example, the results of the Manpower talent survey: [online] https://www.manpowergroup.com/talent-shortage-2016. 
requirements, and steps need to be taken to ensure that this information is then made available to all concerned, especially young people who are making decisions regarding their future studies (Gontero and Zambrano, 2018). As observed by Rathelot and Van Rens (2017), however, this mismatch should also be addressed from the demand side by improving the way labour markets function (including employers' wage-setting practices) so that the shortages of given skills are reflected more clearly in higher salaries.

The lag in the acquisition of some of the skills needed to use new technologies efficiently is mirrored in the generation gap, since younger generations are much more adept in this sense than older generations are (OECD, 2016). A workplace-centred, inter-company approach is needed in order to build on the skills of persons who are already in the workforce (OECD/ILO, 2017). On-the-job training is a good way to bring existing employees' skills into line with current demand. This can be coupled with sectoral initiatives coordinated by chambers of commerce or other employers' associations to allay individual companies' fears that, once they have retrained their employees, those people may leave for employment elsewhere. A three-pronged approach that also involves workers' organizations in identifying demand and appropriate training mechanisms - e.g. skills certification systems - has been shown to contribute to the effectiveness of these processes. Online learning options are another low-cost way to enhance training outcomes (Frey, 2017).

The underrepresentation of women in technology-related occupations with strong growth potential, which threatens to widen the existing gap between men and women in the labour market, underscores the need to mainstream a gender perspective into training efforts. There are two positive developments in this regard. First, while, international comparisons show that, among persons between the ages of 55 and 65, men generally have greater problem-solving abilities in a technology-rich environment than women do, the results are mixed when it comes to the 25-34 age group, with women outperforming men in roughly half of the countries. This would suggest that, in the younger generations, with their greater proximity to new technologies, this kind of differential will not be seen between men's and women's learning abilities in this type of environment (OECD, 2017, p. 107). Second, the wage premium for ICT-intensive tasks is greater for women than it is for men, which may encourage more women to acquire ICT skills (OECD, 2017, p. 48). ${ }^{16}$

\section{Concluding remarks}

This analysis has taken a conditioned contextual approach to the assessment of the possible impact of technological changes on employment based on the belief that the compensatory, deterministic and unconditional contextual approaches do not capture the complexity of the technological, economic and social processes associated with these changes and thus do not provide useful insights for the formulation of public policies that will capitalize upon their development-enhancing potential and mitigate their negative impacts.

This having been said, in Latin America and around the world, a great deal of uncertainty persists as to the impact that new technological advances on employment and on the nature of work. It is known, however, that there will be some extent of job destruction as new technologies are brought into the workplace and as global value chains are restructured. According to what appear to be realistic estimates, net job destruction may amount to between 1\% and 2\% (3.38 million jobs) of total employment in Latin America by 2030 and to 5\% of formal sector jobs (around 8 million jobs) by 2055. This, however, would be a minimum figure for job destruction relating to jobs that involve a large proportion of automatable tasks. A conditioned contextual line of reasoning would suggest that, setting aside jobs having a large number of automatable components, the net result in terms of job destruction and job creation will depend upon the actions of the parties involved, although they cannot act with absolute

\footnotetext{
${ }^{16}$ This does not mean that women in these professions earn more than men but rather that the wage gap between these women and women in other occupations is greater than the wage gap between men in ICT occupations and men employed in other types of activities.
} 
freedom because their scope of action is conditioned by the characteristics of the technologies that become available as time goes on. Thus additional job losses will ensue if production processes -and particularly the human labour they involve - are not adapted to the emerging technological context and - as the opposite also holds true - if those technologies are not adapted to human beings.

In Latin America and the Caribbean, one of the obstacles to the introduction of new technologies is the low cost of labour, since the existence of cheap labour means that new technologies must trigger a bigger jump in productivity in order for it to be profitable to introduce them. Other obstacles include the cost of acquiring, maintaining and updating these technologies, the region's limited extent of innovation and adaptation capacity and its shortcomings in terms of infrastructure. These factors curb the pace of transition to new technologies, which, on the one hand, softens the impact of direct job destruction but, on the other, they also make it take longer to take advantage of the potential offered by these technologies and thus slow down new job creation.

It appears that, rather than actual job destruction, the greatest or most widespread impact of these technological changes will be seen in the changing nature of how people work and what kinds of jobs they perform. As new technologies are incorporated into the performance of certain tasks, they will have to be integrated into the varied set of tasks performed in any given job in different ways. This being so, education and training systems will have to adapt to the sweeping changes that these technological changes will bring in terms of the job skills that are in demand.

First, the knowledge and skills gaps that, according to comparative studies, put Latin America and the Caribbean at a disadvantage will have to be closed (ILO, 2016c). Given this situation and the differentiated impact that the introduction of new technologies appears to have on men and women, along with the biases existing in the region's education and training systems, the adoption of a gender perspective is essential.

Second, new technologies are opening the way for a much wider range of different forms of employment, which poses new challenges for the design of labour institutions that will realize the productive potential of these new ways of working without sacrificing workers' labour rights or job quality. In the specific case of Latin America, it appears that the loss of mid- and high-productivity jobs in the formal sector is more likely to give way to an increase in low-productivity employment in the informal sector rather than to an outright decrease in the number of employed persons.

It should also be borne in mind that technological changes are not the only kinds of changes that are taking place. The ageing of the population in many countries of the region is generating new types of needs that require an integrated response. In addition, major changes need to be made in the energy matrix and in production and consumption patterns in order to ensure that growth will be sustainable (ECLAC, 2016).

Thus, even if new technologies were not posing any threat to employment, Latin America would still need to make a series of structural changes in order to transform its production structure, and public policies focused on this objective will need to provide a framework for the incorporation of new technologies into that structure. New technologies could therefore allow the region to make a leap forward in its development process by enabling it to move closer to the production frontier without first having to become competitive in areas of production in which traditional technologies still predominate.

The complexity of this challenge and the need for policy sustainability call for a participatory approach that is in line with the compacts for equality, sustainability and structural change proposed by ECLAC (2014).

In the aggregate, it is difficult to estimate the net impact of technological change in terms of the number of jobs that will be eliminated and the number of new jobs that will be created. What is clear, however, is that there is a need to leverage human-technology interactions and adapt the workforce's skills and competencies to new demands and opportunities while at the same time addressing the threat of an intensification of existing and emerging inequalities and the new challenges that this poses for labour institutions. 


\section{Bibliography}

Aaronson, D. and B. J. Phelan (2017), "Wage shocks and the technological substitution of low-wage jobs", Working Paper, No. 2017-3, Chicago, Federal Reserve Bank of Chicago.

Aboal, D. and G. Zunino (2017), "Innovación y habilidades en América Latina", Integración and Comercio, No. 42, Washington, D.C., Inter-American Development Bank (IDB).

Acemoglu, D. and D. Autor (2012), "What does human capital do? A review of Goldin and Katz's The Race between Education and Technology", Journal of Economic Literature, vol. 50, No. 2, Nashville, American Economic Association.

Acemoglu, D. and P. Restrepo (2017), "Robots and jobs: evidence from US labor markets", NBER Working Paper, No. 23285, Cambridge, National Bureau of Economic Research (NBER).

(2016), "The race between machine and man: implications of technology for growth, factor shares and employment”, NBER Working Paper, No. 22252, Cambridge, National Bureau of Economic Research (NBER).

Adigital (Spanish Association of the Digital Economy)/GOVUP (2017), Trabajo en plataformas digitales: análisis y propuestas de regulación [online] https://www.adigital.org/informes-estudios/trabajo-enplataformas-digitales/.

Akçomak, S., S. Kok and H. Rojas-Romagosa (2016), "Technology, offshoring and the task content of occupations in the United Kingdom", International Labor Review, vol. 155, No. 2, Hoboken, Wiley.

Arntz, M., T. Gregory and U. Zierahn (2016), "The risk of automation for jobs in OECD countries. A comparative analysis", OECD Social, Employment and Migration Working Paper, No. 189, Paris, OECD Publishing.

Artecona, R. and T. Chau (2017), "Labour issues in the digital economy", Studies and Perspectives seriesECLAC Office in Washington, No. 17 (LC/TS.2017/66), D.C., Economic Commission for Latin America and the Caribbean (ECLAC).

Autor, D. (2015), "Why are there still so many jobs? The history and future of workplace automation", The Journal of Economic Perspectives, vol. 29, No. 3, Nashville, American Economic Association.

(2013), "The 'task approach' to labor markets: an overview", NBER Working Paper, No. 18711, Cambridge, National Bureau of Economic Research (NBER).

Baily, M. N. and N. Montalbano (2016), "Why is US productivity growth so slow? Possible explanations and policy responses", Hutchins Center Working Paper, No. 22, Washington, D.C., Hutchins Center on Fiscal \& Monetary Policy at Brookings.

Becker, S. O. and M.-A. Muendler (2014), "Trade and tasks: an exploration over three decades in Germany" [online] http://econweb.ucsd.edu/muendler/papers/tradtask.pdf.

Bensusán, G., W. Eichhorst and J. M. Rodríguez (2017), "Las transformaciones tecnológicas y sus desafíos para el empleo, las relaciones laborales y la identificación de la demanda de cualificaciones", Project Documents (LC/TS.2017/111), Santiago, Economic Commission for Latin America and the Caribbean (ECLAC).

Berger, T., C. Chen and C. B. Frey (2017), "Cities, industrialization, and job creation: evidence from emerging economies" [online] https://www.oxfordmartin.ox.ac.uk/downloads/JEG_Manuscript.pdf.

Bessen, J. (2015), "Toil and technology", Finance \& Development, vol. 52, No. 1, Washington, D.C., International Monetary Fund (IMF).

BMAS (Federal Ministry of Labor and Social Affairs) (2017), Weißbuch Arbeiten 4.0, Berlin https://www.bmas. de/SharedDocs/Downloads/DE/PDF-Publikationen/a883-weissbuch.pdf?_blob=publicationFile\&v=9.

Cimoli, M. and others (eds.) (2017), Políticas industriales y tecnológicas en América Latina (LC/TS.2017/91), Santiago, Economic Commission for Latin America and the Caribbean (ECLAC)/German Agency for International Cooperation (GIZ).

Diario Financiero (2017a), "Diputados promueven cambio para establecer 'desconexión digital' después del trabajo", Santiago, 3 February.

(2017b), "¿Nuevos tiempos? Los robots ponen en jaque el derecho a huelga de los trabajadores", Santiago, 17 May.

ECLAC (Economic Commission for Latin America and the Caribbean) (2017), Summary of the Chair of the Forum of the Countries of Latin America and the Caribbean on Sustainable Development [online] https:// foroalc2030.ECLAC.org/2017/es/documentos/resumen-la-presidencia-foro-paises-america-latina-caribedesarrollo-sostenible.

(2016), Horizons 2030: Equality at the Centre of Sustainable Development (LC/G.2660/ Rev.1), Santiago. (2014), Compacts for Equality: Towards a Sustainable Future (LC/G.2586(SES.35/3)), Santiago. 
Edin, P.-A. and others (2017), "The rising return to non-cognitive skill", IZA Discussion Paper, No. 10914, Bonn, Institute of Labor Economics (IZA).

Fiszbein, A., C. Cosentino and B. Cumsille (2016), The Skills Development Challenge in Latin America: Diagnosing the Problems and Identifying Public Policy Solutions, Washington, D.C., Inter-American Dialogue and Mathematica Policy Research.

Freeman, R. B. and R. H. Oostendorp (2000), "Wages around the world: pay across occupations and countries", NBER Working Paper, No. 8058, Cambridge, National Bureau of Economic Research (NBER).

Frey, C. B. (2017), "¿Trabajadores versus robots? Cómo ganar el duelo más importante del siglo XXl”, Integración y Comercio, No. 42, Washington, D.C., Inter-American Development Bank (IDB).

Frey, C. B. and M. A. Osborne (2013), "The future of employment: how susceptible are jobs to computerisation?", Technological Forecasting and Social Change, vol. 114, Amsterdam, Elsevier.

Gontero, S. and M. J. Zambrano (2018), "La construcción de sistemas de información sobre el mercado laboral en América Latina", Macroeconomics of Development series, No. 193 (LC/TS.2018/18), Santiago, Economic Commission for Latin America and the Caribbean (ECLAC).

Gordon, R. (2016), The Rise and Fall of American Growth: The U.S. Standard of Living since the Civil War, Princeton, Princeton University Press.

Graetz, G. and G. Michaels (2017), "Is modern technology responsible for jobless recoveries?", American Economic Review, vol. 107, No. 5, Nashville, American Economic Association.

Hathaway, I. and M. Muro (2016), "Tracking the gig economy: new Numbers", Brookings, 13 October [online] https://www.brookings.edu/research/tracking-the-gig-economy-new-numbers.

IE/IDB/MIF (IE Business School/Inter-American Development Bank/Multilateral Investment Fund) (2016), Economía colaborativa en América Latina, Madrid.

ILO (International Labor Organization) (2016a), "Los cambios tecnológicos y el trabajo en el futuro: cómo lograr que la tecnología beneficie a todos", Nota Informativa, No. 1, Geneva.

(2016b), "Un futuro lleno de retos para las relaciones de trabajo: ¿es momento de consolidar o de buscar alternativas?", Nota Informativa, No. 3, Geneva.

(2016c), Panorama Laboral 2016: América Latina y el Caribe, Lima.

(2015), World Employment and Social Outlook: Trends 2015, Geneva.

IMF (International Monetary Fund) (2017), World Economic Outlook 2017: Gaining Momentum?, Washington, D.C.

Kinkel, S. (2012), "Trends in production relocation and backshoring activities: changing patterns in the course of the global economic crisis", International Journal of Operations \& Production Management, vol. 32, No. 6, Bingley, Emerald Group Publishing.

Koch, H. (2017), "Zufrieden, aber kaum abgesichert", Taz (Die Tageszeitung), Berlin, 20 April [online] http:// taz.de/Nerdi-Umfrage-zur-Selbststaendigkeit/!5402549/.

KPMG International Cooperative (2016), Rise of the Humans: The Integration of Digital and Human Labor, Amstelveen [online] https://assets.kpmg.com/content/dam/kpmg/xx/pdf/2016/11/rise-of-the-humans.pdf.

Krull, S. (2016), "El cambio tecnológico y el nuevo contexto del empleo: tendencias generales y en América Latina", Project Documents (LC/W.725), Santiago, Economic Commission for Latin America and the Caribbean (ECLAC).

Manpower Group (2018), Skills Revolution 2.0. Robots Need not Apply: Human Solutions for the Skills Revolution [online] https://www.manpowergroup.com/wps/wcm/connect/59db87a7-16c6-490d-ae701bd7a322c240/Robots_Need_Not_Apply.pdf?MOD=AJPERES.

(2017), The Skills Revolution: Digitalization and Why Skills and Talent Matter [online] https://www.manpowergroup.

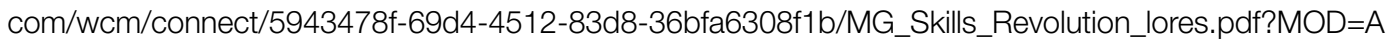
JPERES\&amp;CACHEID=ROOTWORKSPACE-5943478f-69d4-4512-83d8-36bfa6308f1b-my5RaOM.

McKinsey Global Institute (2017a), A Future that Works: Automation, Employment, and Productivity, McKinsey \& Company.

(2017b), Jobs Lost, Jobs Gained: Workforce Transitions in a Time of Automation, McKinsey \& Company.

Miller, C. C. (2017), "Why men don't want the jobs done mostly by women”, The New York Times, New York, 4 January [online] https://www.nytimes.com/2017/01/04/upshot/why-men-dont-want-the-jobs-donemostly-by-women.html?_r=0.

Mokyr, J., C. Vickers and N. L. Ziebarth (2015), "The history of technological anxiety and the future of economic growth: Is this time different?", The Journal of Economic Perspectives, vol. 29, No. 3, Nashville, American Economic Association.

Novick, M. (2018), "El mundo del trabajo: cambios y desafíos en materia de inclusión", Social Policy series, No. 228 (LC/TS.2018/2), Santiago, Economic Commission for Latin America and the Caribbean (ECLAC). 
(2017), "Metodologías aplicadas en América Latina para anticipar demandas de las empresas en materia de competencias técnicas y profesionales", Macroeconomics of Development series, No. 187 (LC/TS.2017/37), Santiago, Economic Commission for Latin America and the Caribbean (ECLAC).

OECD (2017), OECD Science, Technology and Industry Scoreboard 2017: The Digital Transformation, Paris, OECD Publishing.

_ (2016), Skills for a Digital World: Policy Brief on the Future of Work, Paris, OECD Publishing.

OECD/CAF/ECLAC (Organization for Economic Cooperation and Development/Andean Development Corporation/Economic Commission for Latin America and the Caribbean) (2016), Latin American Economic Outlook 2017: Youth, Skills and Entrepreneurship, Paris, OECD Publishing.

OECD/LO (Organization for Economic Cooperation and Development/International Labor Organization) (2017), Better Use of Skills in the Workplace: Why It Matters for Productivity and Local Jobs, Paris.

Pratt, G. A. (2015), "Is a Cambrian explosion coming for robotics?", The Journal of Economic Perspectives, vol. 29, No. 3, Nashville, American Economic Association.

Randstad (2016), Randstad Workmonitor 2016 - Q4 [online] https://cdn2.hubspot.net/hubfs/481927/ Randstad\%20Workmonitor_global_report_Dec2016\%20(8).pdf?submissionGuid=959a4dce-65d7-485ab38c-829ce90182d2.

Rathelot, R. and T. van Rens (2017), "Rethinking the skills gap", IZA World of Labor, No. 391, Bonn, Institute of Labor Economics (IZA).

Saxer, M. (2017), “¿Cómo crear empleos en la era digital?”, Nueva Sociedad, Buenos Aires, April [online] http://nuso.org/articulo/como-crear-empleos-en-la-era-digital/.

Schwab, K. (2016), "The Fourth Industrial Revolution: what it means, how to respond", World Economic Forum, Geneva, 14 June [online] https://www.weforum.org/agenda/2016/01/the-fourth-industrial-revolutionwhat-it-means-and-how-to-respond/.

Shiller, R. (2017), "Robotization without taxation?", Project Syndicate, Prague, 22 March [online] https://www. project-syndicate.org/commentary/temporary-robot-tax-finances-adjustment-by-robert-j--shiller-2017-03.

Sundararajan, A. (2017), "Capitalismo colaborativo", Integración y Comercio, No. 42, Washington, D.C., Inter-American Development Bank (IDB).

Tarabusi, C. C. (1997), "Technology and employment: the role of organisational change and learning", Science Technology Industry Review, No. 20, Paris, OECD Publishing.

United Nations (2017), Report of the Special Rapporteur on Extreme Poverty and Human Rights (A/HRC/35/26), Human Rights Council, 22 March.

Weller, J., S. Gontero and S. Campbell (2019), "Cambio tecnológico y empleo: una perspectiva latinoamericana. Riesgos de la sustitución tecnológica del trabajo humano y desafíos de la generación de nuevos puestos de trabajo", Macroeconomics of Development series, No. 201 (LC/TS.2019/37), Santiago, Economic Commission for Latin America and the Caribbean (ECLAC).

Weller, J. and C. Kaldewei (2014), "Crecimiento económico, empleo, productividad e igualdad”, Inestabilidad and desigualdad. La vulnerabilidad del crecimiento en América Latina y el Caribe, J. A. Fuentes (ed.), ECLAC Books, No. 128 (LC/G.2618-P), Santiago, Economic Commission for Latin America and the Caribbean (ECLAC).

Wolf, M. (2016), "The tide of globalisation is turning", London, Financial Times, 6 September [online] https:// www.ft.com/content/87bb0eda-7364-11e6-bf48-b372cdb1043a.

World Bank (2016), World Development Report 2016: Digital Dividends, Washington, D.C.

World Economic Forum (2018), Towards a Reskilling Revolution: A Future of Jobs for All, Cologne/Geneva. (2016), The Future of Jobs: Employment, Skills and Workforce Strategy for the Forth Industrial Revolution, Geneva. 